\title{
Problematyka marnowania żywności w Polsce, a kształtowanie wzorca zrównoważonej konsumpcji
}

\author{
The Problem of Food Wasting in Poland and Shaping the Pattern of Sustainable Consumption
}

\author{
Mikołaj Niedek, Karol Krajewski \\ Narodowy Instytut Kultury i Dziedzictwa Wsi \\ ORCID: MN https://orcid.org/0000-0001-5241-5150; KK https://orcid.org/0000-0001-7311-8024• mikolaj.niedek@nikidw.edu.pl \\ Zgłoszono: 20.01.2021; zrecenzowano: 12.04.2021; zaakceptowano do druku: 21.04.2021
}

\begin{abstract}
Streszczenie: Celem niniejszego artykułu jest nakreślenie kierunków działań związanych z kształtowaniem trwałej i zrównoważonej konsumpcji, na tle wyników badań i analiz w zakresie poziomu strat i marnotrawstwa żywności w łańcuchu żywnościowym przeprowadzonych w ramach projektu badawczego PROM. Punktem wyjścia jest zarysowanie problematyki strat i marnotrawstwa żywności w świetle danych dostępnych na poziomie globalnym, europejskim i krajowym oraz pokazanie, że problematyka ta ma charakter interdyscyplinarny - społeczny, ekonomiczny, ekologiczny i że stanowi właściwy przedmiot refleksji ekofilozoficznej i etyczno-środowiskowej. Negatywne dla środowiska, społeczeństwa i gospodarki tendencje związane ze współczesnym poziomem strat i marnotrawstwa żywności na wszystkich etapach łańcucha rolno-żywnościowego, wymagają zmian obecnych wzorców konsumpcji na zgodne z wymogami trwałego i zrównoważonego rozwoju. Transformacja ta wymaga wprowadzenia zmian o charakterze aksjologicznym i etycznym, które są szczególnie wskazane na końcowym etapie łańcucha żywnościowego - nabywania żywności przez konsumentów i sposobu postępowania z nią w gospodarstwach domowych. Artykuł kreśli również kierunki dalszych badań mających na celu przygotowanie właściwej, całościowej podstawy teoretycznej do projektowania adekwatnych działań implementacyjnych trwałego i zrównoważonego rozwoju w obszarze konsumpcji.
\end{abstract}

Słowa kluczowe: straty i marnotrawstwo żywności, łańcuch rolno-żywnościowy, wzorzec trwałej i zrównoważonej konsumpcji, wdrażanie zrównoważonej konsumpcji

\begin{abstract}
The aim of the article is to outline the directions of appropriate activities related to the development of sustainable consumption. The background are the results of research and analysis on the level of food losses and wastage in the food chain, carried out as part of the PROM research project. The starting point of the article is to outline the issue of food losses and wastage in the light of the data available at the global, European and national levels, and to show that this issue is interdisciplinary - social, economic, and environmental, and that it is a proper subject of ecophilosophical and ecoethical reflection. The trends, which are negative for the environment, society and economy, related to the contemporary level of food losses and wastage at all stages of the agri-food chain, require changes in the current consumption patterns to comply with the requirements of sustainable development. This transformation requires the changes in axiological and ethical patterns, which are especially recommended at the final stage of the food chain - the purchase of food by consumers and the way of dealing with it in households. The article also outlines the directions of further research aimed at preparing an appropriate, comprehensive theoretical basis for designing adequate implementation activities for sustainable development of consumption.
\end{abstract}

Keywords: food losses and wastage, agri-food chain, pattern of sustainable consumption, implementation of sustainable consumption 


\section{Wprowadzenie}

Według danych światowej Organizacji ds. Wyżywienia i Rolnictwa FAO (Food and Agriculture Organization), globalnie marnuje się ok. 1/3 wytwarzanej żywności (Gustavsson et al. 2011). Ma to wiele negatywnych skutków społecznych, gospodarczych, energetycznych i środowiskowych - począwszy od zużycia zasobów naturalnych, gleby, wody, energii, po emisję zanieczyszczeń, gazów cieplarnianych i wytwarzanie odpadów opakowaniowych i żywnościowych. W krajach Unii Europejskiej (UE), według dostępnych szacunków, marnuje się około $88 \mathrm{mln}$ ton żywności rocznie, a koszty z tym związane szacuje się na 143 mld euro (FUSIONS 2016). Straty i marnotrawstwo żywności występują na wszystkich etapach łańcucha rolno-żywnościowego, począwszy od produkcji podstawowej (rolnictwo), poprzez transport i przechowywanie, przetwórstwo, dystrybucję i handel, aż po konsumpcję w gospodarstwach domowych i obiektach żywienia zbiorowego oraz gastronomii. Marnotrawstwo żywności postrzegane jest jako duży problem ekologiczny i ekonomiczny, ale również etyczny. W strukturze strat marnotrawstwa w krajach rozwiniętych gospodarstwa domowe, a więc konsumenci, odpowiedzialni są za generowanie największej ilości marnowanej żywności (Kosseva and Webb 2013).

Według raportu FUSIONS Food waste data set for $E U$-28, gospodarstwa domowe, jako końcowe ogniwo łańcucha rolno-żywnościowego, odpowiadają za 53\% powstających odpadów żywnościowych (FUSIONS 2015). Widoczne są jednak znaczące różnice między krajami UE w zakresie wytwarzanych odpadów, a ilości te - według szacunków - wynoszą do 25-133 kg/os./ rok, podczas gdy w Polsce jest to $54 \mathrm{~kg}$ odpadów żywności na osobę na rok (Monier et al. 2010). Przeciwdziałanie stratom i marnotrawstwu żywności jako działanie na rzecz oszczędności zasobów wpisuje się w koncepcję trwałego i zrównoważonego rozwoju (sustainable development), jak również w przedmiot zainteresowania etyki środowiskowej (Ganowicz-Bączyk 2015). Z uwagi na fakt, że gospodarstwa domowe stanowią punkt krytyczny w zarządzaniu łańcuchem strat żywności, to zrównoważona konsumpcja (sustainable consumption) żywności stanowi klucz do ograniczenia strat w łańcuchu żywnościowym. Na poziomie globalnym, w ramach celów zrównoważonego rozwoju, Zgromadzenie Ogólne Organizacji Narodów Zjednoczonych (ONZ) w 2015 r. przyjęło cel zmniejszenia o połowę do $2030 \mathrm{r}$. marnotrawstwa żywności na mieszkańca, na poziomie sprzedaży w handlu detalicznym i konsumpcji gospodarstw domowych oraz zmniejszenia strat żywności w całym łańcuchu żywnościowym. Jednak, aby skutecznie zmniejszyć marnotrawienie żywności przez konsumentów, konieczne jest dokładne zrozumienie tego, jakie czynniki wpływają na postrzeganie i zachowania konsumentów związane z marnotrawieniem żywności (Aschemann-Witzel et al. 2015), a w konsekwencji, co decyduje o zrównoważonej konsumpcji żywności w kontekście ograniczenia marnotrawstwa i strat żywności.

\section{Definiowanie strat i marnotrawstwa żywności}

W problematyce strat i marnotrawstwa żywności (food loss and waste) ważną rolę odgrywa właściwe definiowanie i rozumienie terminów z nią związanych, obejmujących kluczowe kategorie, jak: żywność i jej części jadalne i niejadalne, ubytki naturalne, produkty uboczne, straty, marnowanie i odpady żywności, które są różnie definiowane na poziomie globalnym i UE (Niedek i in. 2019). Według Instytutu Ekonomiki Rolnictwa i Gospodarki Żywnościowej - Państwowego Instytutu Badawczego (IERiGŻ-PIB) należy wprowadzić rozróżnienie pomiędzy stratami żywności, występującymi po stronie podaży, a marnotrawstwem i marnowaniem żywności występującym po stronie popytu (Kwasek 2016). Często jednak jeden termin ma wiele znaczeń bądź różny zakres desygnatów, w wyniku czego nie można dokonać porównań danych opartych na różnych 


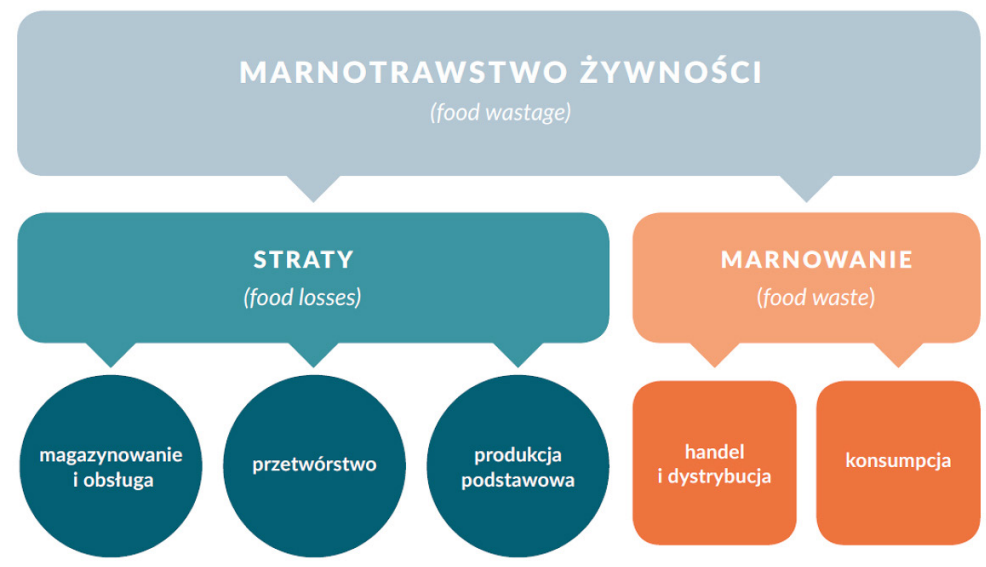

Ryc. 1. Powody wyrzucania żywności wg wyników badań w ramach projektu PROM (Łaba 2020, 119)

definicjach. Parlament Europejski w 2012 r. zaproponował, ażeby za straty i marnotrawstwo uznawać „produkty żywnościowe odrzucone poza łańcuch rolno-żywnościowy ze względów gospodarczych, estetycznych lub z powodu zbliżającej się daty przydatności, które nadal jednak nadają się do spożycia i mogą być przeznaczone do konsumpcji przez ludzi, a które z braku możliwego alternatywnego sposobu wykorzystania przeznacza się do likwidacji i utylizacji, co powoduje negatywne efekty zewnętrzne pod względem wpływu na środowisko, kosztów gospodarczych i braku dochodów dla przedsiębiorstw" (Rezolucja Parlamentu Europejskiego 2012). W ustawie z dnia 19 lipca 2019 r. o przeciwdziałaniu marnowaniu żywności (dotyczącej wszakże tylko etapu dystrybucji żywności) przyjęto, że marnowanie żywności to „wycofywanie z etapu dystrybucji żywności, która spełnia wymogi prawa żywnościowego, w szczególności ze względu na zbliżający się upływ terminu przydatności do spożycia lub daty minimalnej trwałości lub ze względu na wady wyglądu tych środków spożywczych albo ich opakowań i przeznaczanie ich do unieszkodliwiania jako odpady" (Dz.U. 2019, poz. 1680). Wspólnym dla wielu ujęć jest założenie, że pod pojęciem strat i marnotrawstwa żywności należy łącznie rozumieć surowce i produkty żywnościowe wytworzone w celach konsumpcyjnych, które nie zostały spożyte przez ludzi, czyli nie zostały wykorzystane zgodnie z pierwotnym przeznaczeniem żywności, na każdym etapie łańcucha żywnościowego (Bilska i Kołożyn-Krajewska 2016). Nadal jednak w badaniach poziomu strat i marnotrawstwa żywności występuje szereg metodologicznych barier, co utrudnia interpretację uzyskanych wyników oraz ich porównanie w układzie branż sektora żywnościowego i pomiędzy krajami (Krajewski et al. 2019).

\section{Pomiar strat i marnotrawstwa żywności}

Wzorem definicji przyjmowanych na poziomie UE i globalnym należy powiązać marnotrawstwo z powstawaniem odpadów żywności i monitorować je poprzez pomiar ich ilości - substancji wyłączanych z łańcucha rolno-spożywczego, co zgodne jest z koncepcją gospodarki o obiegu zamkniętym (Komunikat Komisji 2018). W maju 2019 r. opublikowana została decyzja delegowana Komisji Europejskiej 2019/1597 uzupełniająca dyrektywę Parlamentu Europejskiego i Rady 2008/98/WE w odniesieniu do wspólnej metody i minimalnych wymagań jakościowych dla jednolitego pomiaru poziomów odpadów żywności (Decyzja delegowana Komisji 2019), która w istotnym zakresie ujednoliciła metodykę pomiaru marnowania żywności poprzez pomiar wytwarzanych odpadów żywności. Pierwszym krokiem do podjęcia skutecznych działań zaradczych jest właściwe oszacowanie skali strat i marnotrawstwa żywności na poziomie poszczególnych ogniw i uczestników łańcucha 
rolno-żywnościowego. Zadanie takie podjęto w projekcie badawczym pt. „Opracowanie systemu monitorowania marnowanej żywności i efektywnego programu racjonalizacji strat i ograniczania marnotrawstwa żywności (PROM)" ${ }^{1}$. W połowie 2020 r. opublikowany został pierwszy raport sprawozdający wyniki badań strat i marnotrawstwa żywności dla poszczególnych ogniw łańcucha rolno-żywnościowego (ryc. 1) oraz branż gospodarki żywnościowej: mięsnej (drobiu, trzody chlewnej i bydła) mleczarskiej, rybnej (akwakultura), owocowo-warzywnej, piekarsko-cukierniczej, zbożowej i nasion roślin oleistych (rzepaku i rzepiku) (Łaba 2020).

Z perspektywy trwałego i zrównoważonego rozwoju, do strat i marnotrawstwa żywności powinno wliczać się również żywność traconą zarówno w wyniku nadmiernej produkcji żywności (nadprodukcji), jak i nadmiernej konsumpcji (konsumpcjonizm), które przyczyniają się do marnotrawstwa zasobów, w tym zasobów żywnościowych (Bilska et al. 2015). Na nadmierną konsumpcję jako źródło generowania marnotrawstwa zwraca uwagę IERiGŻ-PIB w cytowanym raporcie oraz inni badacze problemu (Stępień i Dobrowolski 2017). Według J. Parfitt marnotrawstwo żywności na końcowym etapie łańcucha rolno-żywnościowego jest efektem zachowań konsumentów, na które wpływ ma konsumpcjonizm i nieracjonalne pod względem żywieniowym i ekologicznym wzorce tych zachowań (Parfitt et al. 2010). Poniżej zostaną podsumowane wyniki badań poziomów strat i marnotrawstwa żywności stanowiących rezultaty badawcze projektu PROM dla poszczególnych ogniw łańcucha rolno-żywnościowego i badanych sektorów żywnościowych. Szerzej ujęty zostanie

1 Projekt PROM (www.projektprom.pl) jest finansowany przez Narodowe Centrum Badań i Rozwoju i realizowany w okresie od 1.09.2018 do 31.08.2021 przez konsorcjum w składzie: Federacja Banków Żywności, Instytut Ochrony Środowiska, Krajowy Ośrodek Wsparcia Rolnictwa, Szkoła Główna Gospodarstwa Wiejskiego, Polskie Towarzystwo Technologów Żywności w ramach Programu GOSPOSTRATEG 1/385753/1/2018. problem marnowania żywności w gospodarstw domowych wraz z identyfikacją przyczyn tego zjawiska, które składają się na dominujący wzorzec konsumpcji i postępowania z żywnością.

\section{Skala strat i marnotrawstwa w ogniwach lańcucha żywnościowego według wyników projektu PROM}

W projekcie PROM straty i marnotrawstwo żywności były definiowane i badane w głównych ogniwach łańcucha żywnościowego: produkcji podstawowej (rolniczej), przetwórstwie spożywczym, transporcie i magazynowaniu artykułów żywnościowych, handlu detalicznym oraz na poziomie gospodarstw domowych i gastronomii. W produkcji podstawowej (rolnictwie) roczne straty w skali kraju szacowane są na poziomie ponad $2 \mathrm{mln}$ ton. Głównym miejscem strat pod względem masy, spośród badanych sektorów, był sektor zbożowy generujący ponad $72 \%$ wszystkich strat (niemal 1,5 mln ton). Znaczny udział w ogólnym poziomie strat miał sektor owocowo-warzywny odpowiadający za niemal 24\% wszystkich strat (prawie $0,5 \mathrm{mln}$ ton). Pozostałe sektory generowały łącznie mniej niż 5\% wszystkich strat na poziomie gospodarstw rolnych.

W ogniwie przetwórstwa spożywczego rozmiary strat w przedsiębiorstwach oceniono na podstawie dwóch wskaźników, tj.: udziału łącznej masy strat w masie surowców przyjętych na produkcję oraz udziału łącznej masy strat w masie wyrobów gotowych wydanych z magazynu. Najwyższy odsetek strat według danych za rok 2018 odnotowano wśród badanych firm z sektora przetwórstwa owocowo-warzywnego (odpowiednio 6,44\% i 8,58\%), a następnie z sektora mięsnego $(5,39 \%$ i $3,19 \%)$ i olejarskiego (2,22\% i 4,94\%). Pod względem ilości najniższy udział strat zaobserwowano wśród podmiotów z sektora mleczarskiego (o,005\% i o,53\%) oraz zbożowego (o,42\% i o,45\%). Pomiędzy przedsiębiorstwami z poszczególnych sektorów występowały znaczące różnice w poziomie strat. W obsłudze logistycznej procesów przetwórstwa odsetek 
generowanych strat może wynosić ok. 5\%. Ponad połowę z nich stanowią straty w tym obszarze w odniesieniu do owoców i warzyw (60\%), a także produktów mięsnych (15\%) i rybnych (15\%). Centra dystrybucyjne są najczęściej wskazywane jako podmiot, który może wykazywać wysoki odsetek strat i marnotrawstwa żywności (Krajewski i Lipińska 2017). Jako przyczyny strat podawany był zbyt długi okres przechowywania towarów, nieprzestrzeganie zasad, niedbalstwo pracowników, pośpiech i brak dokładności.

W placówkach handlu detalicznego codziennie ma miejsce usuwanie ze sprzedaży produktów świeżych, takich jak pieczywo $(60,9 \%)$, owoce i warzywa $(48,3 \%)$, niepakowane mięso, drób i ryby $(37,9 \%)$ oraz artykuły chłodnicze z bardzo krótkim terminem przydatności do spożycia $(34,5 \%)$. Najczęściej wskazywaną przez respondentów przyczyną marnotrawstwa żywności w obiektach handlowych okazało się przekroczenie terminu przydatności do spożycia (Kołożyn-Krajewska et al. 2016). W handlu, $\mathrm{w}$ porównaniu $\mathrm{z}$ innymi ogniwami łańcucha żywnościowego, marnotrawstwo żywności jest szacowane na stosunkowo niskim poziomie (Wrzosek et al. 2017). W badaniu PROM zostało ocenione na ok. $7 \%$, ale jest to etap kluczowy w ograniczaniu tego zjawiska marnotrawstwa, choćby ze względu na możliwość łatwego i szybkiego wykorzystania żywności na cele społeczne i redystrybuowania za pomocą organizacji pożytku publicznego do osób potrzebujących (Bilska i Kołożyn-Krajewska 2018).

\section{Marnotrawstwo żywności w gospodarstwach domowych i praktyki konsumpcyjne}

Celem przeprowadzonych w ramach projektu PROM badań dotyczących skali marnowania żywności w gospodarstwach domowych było zidentyfikowanie czynników wpływających na marnotrawstwo żywności przez polskich konsumentów oraz określenie czynników socjodemograficznych, takich jak: wiek, płeć, miejsce zamieszkania, mających wpływ na postępowanie z żywnością ${ }^{2}$. W odniesieniu do etapu początkowego - planowania zakupów stwierdzono, że tylko 4 na 10 respondentów deklarowało, iż przed wyjściem na zakupy sprawdza w domu zawartość szafek i lodówki oraz przygotowuje listę niezbędnych produktów spożywczych. Określono, że zdecydowanie częściej wymienione czynności wykonują kobiety niż mężczyźni. Niespełna 30\% osób biorących udział w badaniu wskazało też, że przed wyjściem na zakupy spożywcze zjada posiłek, by nie robić zakupów z pustym żołądkiem. Około $20 \%$ konsumentów w trakcie zakupów zawsze lub zazwyczaj nabywa produkty spożywcze, których wcześniej nie planowali, przy tym młodsi konsumenci częściej niż starsi nabywają niezaplanowane produkty. W przypadku mieszkańców niewielkich miast (50-100 tys. ludności) to $3 \%$ przyznało, że zawsze lub zazwyczaj kupuje produkty spożywcze na zapas, podczas gdy mieszkańcy pozostałych miejscowości czynili to zdecydowanie częściej. Badano również, jakie podejście reprezentują konsumenci w czasie zakupów względem małych, niekształtnych owoców i warzyw oraz produktów z krótką datą ważności. Niezależnie od płci oraz wieku raczej niechętnie nabywają tego typu produkty i tylko niespełna 10\% respondentów deklarowało, że kupuje niekształtne owoce i warzywa oraz produkty z krótką datą ważności. Kupowanie zbyt dużej ilości towarów, kupowanie na zapas, zakupy impulsywne, niezwracanie uwagi na datę przydatności do spożycia są czynnikami powodującymi, że konsumenci marnują ogromne ilości żywności (Bilska et al. 2020).

W aspekcie postępowania respondentów z żywnością w domu istotnym czynnikiem jest sposób jej przechowywania. Większość (7 na 10) konsumentów zawsze lub zazwyczaj przechowuje żywność zgodnie z rekomendacjami producenta, respondenci dbaja także o zapewnienie ciągłości łańcucha

2 Badania ankietowe zostały przeprowadzone $\mathrm{w}$ ramach projektu PROM na początku $2019 \mathrm{r}$. w grupie 1115 dorosłych respondentów (powyżej 18 roku życia). 
Tab. 1. Zachowania konsumentów mające bezpośredni wypływ na poziom marnowania żywności, wg badań w projekcie PROM

\begin{tabular}{lc}
\hline Rodzaj zachowania/praktyki & Częstość występowania [\%] \\
\hline Sprawdzanie zawartości lodówki przed zakupami & 3 \\
\hline Przygotowywanie listy niezbędnych produktów przed zakupami & 39 \\
\hline Nabywanie produktów, których wcześniej nie planowano & 18,9 \\
\hline Robienie zakupów „na zapas" & 16,7 \\
\hline Spożywanie posiłku przed wyjściem na zakupy (aby nie iść z pustym żołądkiem) & 29,8 \\
\hline $\begin{array}{l}\text { Nienabywanie produktów, które są pełnowartościowe, ale „trochę gorzej wyglądają” } \\
\text { (np. małych, niekształtnych warzyw bądź owoców lub produktów w zdeformowanych } \\
\text { opakowaniach) }\end{array}$ & 50,6 \\
\hline Niespożywanie produktów po upływie daty ich ważności & 58,9 \\
\hline
\end{tabular}

chłodniczego. Tylko 3 na 10 dorosłych Polaków wskazało, że w czasie przechowywania produktów spożywczych zawsze lub zazwyczaj układa je, uwzględniając datę ważności, czyli najbliżej drzwi lodówki/szafki te, które mają datę najkrótszą (zasada FIFO - first in, first out, czyli pierwsze weszło, pierwsze wyszło). Kobiety częściej niż mężczyźni wskazywały, że zawsze lub zazwyczaj przestrzegają warunków przechowywania rekomendowanych przez producenta (K: 74,7\%; M: $58,6 \%)$, produkty nietrwałe natychmiast układają w lodówce (K: 85,5\%; M: 72\%), w lodówce/szafce układają produkty, uwzględniając ich datę ważności (K: 36,8\%; M: 25,5\%).

Aż 62,9\% Polaków deklaruje, że wyrzuca pieczywo. Na kolejnych pozycjach znajdują się: owoce $(57,4 \%)$, warzywa tzw. nietrwałe, typu sałata, rzodkiewka, pomidory czy ogórki $(56,5 \%)$, wędliny $(51,6 \%)$ oraz napoje mleczne $(47,3 \%)$. Najrzadziej wyrzucanymi przez respondentów produktami okazały się: kawa, herbata, kakao (powyżej $80 \%$ wskazań) oraz inne tłuszcze, masło, margaryny itp., nasiona roślin strączkowych, cukier i zamienniki, koncentraty spożywcze typu instant, napoje gazowane i niegazowane oraz soki, słodycze i słone przekąski, konserwy mięsne i rybne, świeże mięso czerwone, jaja (odsetek wskazań 70$80 \%$ ). Respondenci (6-7 na 10) deklarowali, że - z różną częstotliwością - marnują niespożyte posiłki, głównie są to ugotowane ziemniaki, ryż i makaron. Wykazano, że w przypadku ośmiu grup produktów wiek wpływał w istotny sposób na częstotliwość ich wyrzucania. W najstarszej grupie konsumentów, tj. w wieku powyżej 6o lat, wykazano, że najczęściej spośród wszystkich grup wiekowych zdecydowanie deklarowano niewyrzucanie pieczywa, produktów zbożowych, śmietany, serów twarogowych, świeżych owoców, napojów gazowanych i niegazowanych oraz soków, nasion roślin strączkowych, a także gotowych, niezjedzonych komponentów dań. Najczęściej (prawie 7 na 10 respondentów) wskazywanym przez respondentów powodem wyrzucania żywności było jej zepsucie. 40\% respondentów określiło, że wyrzuca żywność z powodu przeoczenia jej daty ważności, a prawie $30 \%$ przyznało, że z powodu przygotowania zbyt dużej ilości jedzenia.

Preferowanym sposobem zapobiegania marnotrawstwu żywności jest redystrybucja żywności na cele społeczne, pozwalająca na przekazanie niesprzedanych produktów bądź takich, których okres przydatności do spożycia zbliża się do końca, osobom o niskim dochodzie i/lub nieposiadającym środków na ich zakup (Bilska et al. 2015). Ten kierunek działania wzmacnia też bezpieczeństwo żywnościowe wielu krajów i regionów i jest zgodny z trendem społecznej odpowiedzialności biznesu w gospodarce.

Procentowy udział powodów marnowania żywności przez konsumentów według wyników badań projektu PROM prezentuje ryc. 2. 


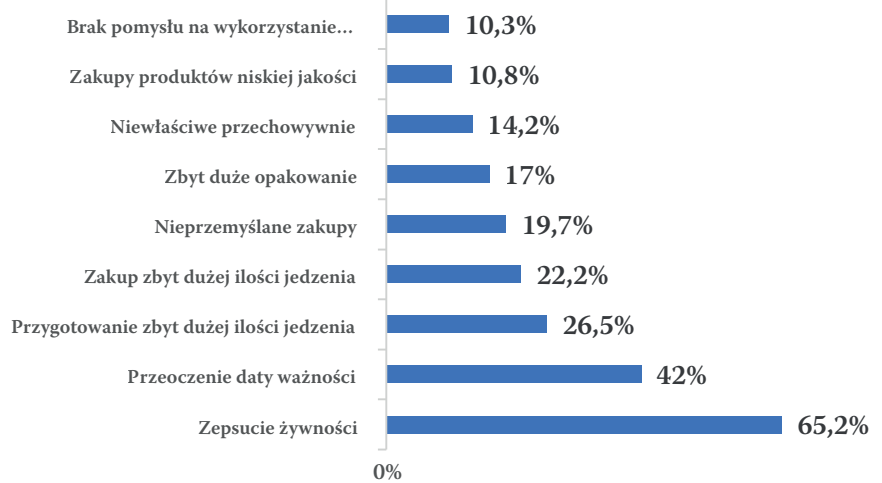

Ryc. 2. Powody wyrzucania żywności wg wyników badań w ramach projektu PROM (Laba 2020, 119)

\section{Przeciwdziałanie marnotrawstwu jako równoważenie wzorca konsumpcji}

W krajach rozwiniętych konsumenci są jednym z największych źródeł marnotrawienia żywności. Aby skutecznie zmniejszyć poziom marnotrawienia żywności przez konsumentów, konieczne jest dokładne zrozumienie tego zjawiska w kontekście czynników wpływających na postrzeganie i zachowania konsumentów związanych z marnotrawieniem żywności oraz realizowanych wzorców konsumpcji pod kątem potrzeby ich równoważenia. Znaczenie wzorców konsumpcji w kontekście zasad zrównoważonego rozwoju ilustruje ryc. 3 . Konsumenci odgrywają kluczową rolę w marnowaniu żywności, nie tylko poprzez decyzje podejmowane w swoich gospodarstwach domowych i podczas zakupów w sklepach. Ich faktyczne lub przewidywane postrzeganie żywności i zachowania związane z zakupem żywności wpływają na decyzje interesariuszy w całym łańcuchu dostaw (Stuart 2009). W kontekście ujawnianych potrzeb konsumentów sprzedawcy stosują standardy estetyczne i narzucają dostawcom żywności normy jakościowe, opierając się na założeniu, że konsumenci będą kupować wyłącznie żywność spełniającą te normy. Prowadzi to do odrzucania produktów i surowców w pełni wartościowych, ale niespełniających tych norm, co rodzi straty na etapie handlu. Produkty żywnościowe, które są marnowane na poziomie

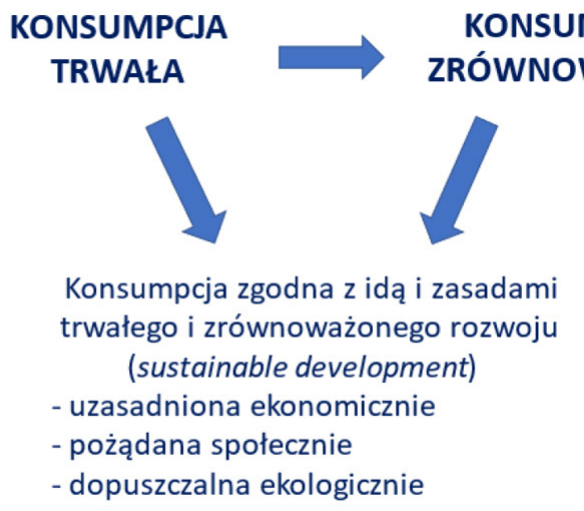

\section{PPCJA} WAŻONA

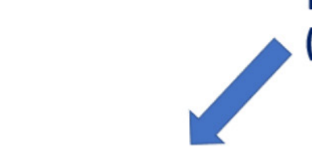

ukierunkowana na produkty zrównoważone (ekologiczne i ekospołeczne jak np. Fair Trade)

\section{KONSUMPCJA}

EKOLOGICZNA I PROSPOLECZNA (odpowiedzialna)

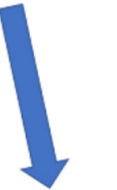

dokonywana z poszanowaniem zasobów, energii i pracy ludzkiej (odpowiedzialne postępowanie $z$ produktami)

Ryc. 3. Relacje pomiędzy wzorcami konsumpcji zgodnymi z zasadami zrównoważonego rozwoju (Niedek 2020) 
konsumenta, mimo że są jadalne lub zbliża się ich data przydatności do spożycia, stanowią żywność suboptymalną, definiowaną jako żywność, którą konsumenci postrzegają jako stosunkowo niepożądaną w porównaniu z innymi podobnymi produktami żywnościowymi (Quested, Ingle, and Parry 2012).

Działania na rzecz zrównoważenia społecznego i ekologicznego konsumpcji podejmowane są systematycznie od początku XXI w., szczególnie zaś od Szczytu Ziemi ONZ w Johannesburgu w 2002 r., w którego Planie Działań znalazła się zmiana nieracjonalnych wzorców konsumpcji i produkcji. W Polsce w 2003 r. przyjęta została Strategia zmian wzorców konsumpcji i produkcji na sprzyjajace realizacji zasad trwałego i zrównoważonego rozwoju. W $2008 \mathrm{r}$. Komisja Europejska opublikowała Komunikat dotyczący planu działania na rzecz zrównoważonej konsumpcji i produkcji (Komunikat Komisji 2008). Kompleksowe działania zmierzające do równoważenia produkcji i konsumpcji zostały określone w dokumentach strategicznych przyjętych w maju $2020 \mathrm{r}$. na poziomie UE w ramach Europejskiego Zielonego Ładu i Strategii, w szczególności w Strategii „od pola do stotu” na rzecz sprawiedliwego, zdrowego i przyjaznego dla środowiska systemu żywnościowego.

Transformacja w kierunku tworzenia zrównoważonych systemów żywnościowych jest ogromną szansą nie tylko dla producentów, lecz także dla konsumentów. Oczekiwania konsumentów, które obecnie zmieniają się, pobudzają w sposób znaczący zmiany na rynku żywności, a tym samym dają sygnał dla zmian w łańcuchu żywnościowym - dla producentów i przetwórców żywności. Transformacja w kierunku zrównoważonego rozwoju daje wszystkim uczestnikom tego łańcucha szanse, aby stali się innowatorami i pionierem na rynku (Komunikat Komisji 2020), a konsumentom nadzieję na osiągnięcie zrównoważonej konsumpcji i ograniczenia strat i marnotrawstwa żywności.

Proekologiczne i prospołeczne równoważenie wzorca produkcji, w literaturze przedmiotu, ujmuje się jako operacjonalizację zasad zrównoważonego rozwoju w odniesieniu do sektora przedsiębiorstw i producentów rolnych, a równoważenie wzorca konsumpcji - jako zmniejszanie negatywnego oddziaływania na zużycie zasobów i środowisko oraz na nierówności społeczne ze strony postaw i zachowań konsumentów. Według D. Kiełczewskiego można wyróżnić dwa kierunki definiowania zrównoważonej konsumpcji i jej modelowego wzorca: 1) opisowy - określający ekonomiczne warunki, których spełnienie oznaczać będzie osiąganie przez realne procesy konsumpcji celów trwałości i zrównoważenia; oraz 2) normatywny - określający pożądany kształt procesów konsumpcji zgodny z koncepcją trwałego i zrównoważonego rozwoju (Kiełczewski 2004, 49).

Normatywny aspekt zrównoważonego wzorca konsumpcji obejmuje również kwestie aksjologiczne związane z systemem i hierarchią wartości, jakimi kieruje się w swoich wyborach człowiek-konsument. Poprzez strukturę swoich preferencji konsumenckich ma on wpływ zarówno na dalsze i bliższe otoczenie społeczne i przyrodnicze, gdyż zarówno rodzaj nabywanych produktów, jak i sposób ich użytkowania oraz postępowania z nimi na etapie poużytkowym oraz postępowania $\mathrm{z}$ odpadami, $\mathrm{w}$ tym odpadami żywności, ma znaczący wpływ na zużycie zasobów oraz na zanieczyszczenie środowiska.

W przypadku postępowania z żywnością i odpadami żywności znaczący jest też wpływ społeczny, gdyż marnotrawstwo żywności przy znaczącej skali głodu na świecie, wykluczenia społecznego i biedy ma również wymiar moralny. W wymiarze ekologicznym konsumpcja niezrównoważona jest też konsumpcją nietrwałą. W opinii H. JastrzębskiejSmolagi „nietrwała konsumpcja, wyrażająca liniową zależność między wzrastającą liczbą ludności świata i wzrastającymi potrzebami konsumpcyjnymi zaspokajanymi przez nadmierną eksploatację zasobów naturalnych nie może być kontynuowana, gdyż grozi globalną katastrofą, wynikającą z przekroczenia 
zdolności absorpcji zanieczyszczeń produkcyjnych przez środowisko naturalne" (Jastrzębska-Smolaga 2000, 72).

Zarówno z punktu widzenia zdrowia, jak i środowiska obecne wzorce konsumpcji żywności nie spełniają wymogów zrównoważenia (FAO and WHO 2019). Podczas gdy średnie spożycie energii, mięsa czerwonego, cukrów, soli i tłuszczów w UE nadal przekracza zalecenia, to spożycie produktów pełnoziarnistych, owoców i warzyw, roślin strączkowych i orzechów jest niewystarczające (Willett et al. 2019, 447). Szacuje się, że w UE w 2017 r. ponad 950 tys. zgonów i ponad 16 mln utraconych lat życia w zdrowiu zostało spowodowanych niezdrową dietą skutkującą głównie chorobami układu krążenia i chorobami nowotworowymi (Centrum Naukowe UE 2020).

Struktura wzorca konsumpcji żywności ma aspekt podmiotowy - związany ze sposobem nabywania (modelem zakupów), przechowywania i postępowania z produktami (na etapie prekonsumpcyjnym, konsumpcyjnym i postkonsumpcyjnym), jak również wymiar przedmiotowy, związany z rodzajem i ilością nabywanych i konsumowanych produktów, które to czynniki łącznie mają znaczący wpływ na finalny poziom marnotrawienia żywności. Refleksja filozoficzna nad wpływem zachowania człowieka na środowisko, ożywione i nieożywione otoczenie przyrodnicze, ale również społeczne, prowadzona była w ramach etyki środowiskowej, uznawanej za praktyczną część filozofii ekologicznej (Tyburski 1999). Problematyka marnotrawstwa stanowi więc również przedmiot zainteresowania proekologicznie zorientowanej etyki i aksjologii, ale także etyki konsumpcji i konsumpcji etycznej, tzw. etycznego konsumeryzmu (Lewicka-Strzałecka 2003) oraz ekominimalizmu, frugalizmu i freeganizmu, jak i foodsharing'u jako praktycznych przykładów zrównoważonych ekospołecznie stylów konsumpcji i życia (Śmiechowska 2015).

Zidentyfikowane w wyżej podsumowanym badaniu nieprawidłowe zachowania respondentów domagają się możliwych form przeciwdziałania, którymi może być zarówno edukacja konsumencka, jak i kształtowanie odpowiedzialnej etyki konsumpcji. Według A. Lewickiej-Strzałeckiej: „Odpowiedzialność ekologiczna bazuje na wiedzy o degradującym wpływie konsumpcji na środowisko naturalne i przejawia się w indywidualnych i zbiorowych zachowaniach konsumenckich mających ograniczyć ten wpływ. Są to szeregi pojedynczo mało znaczących, codziennych zachowań konstytuujących ze względu na swą systematyczną powtarzalność ową cenną dyspozycję do czynienia dobra. Zachowania te mogą między innymi polegać na kupowaniu energo - i materiałooszczędnych produktów, selekcji odpadów, ograniczeniu opakowań, oszczędnym używaniu produktów oraz powstrzymaniu się przed marnotrawstwem żywności. To ostatnie ma miejsce na dużą skalę $\mathrm{w}$ wielu gospodarstwach domowych, w których wyrzuca się pieczywo, mięso, wędliny, warzywa, produkty mleczne w zatrważających ilościach. Szacuje się, że w typowym domu Europejczyka wyrzuca się na śmietnik $20^{-} 30 \%$ żywności. Stanowi to wyrazistą miarę niedostatku cnoty odpowiedzialności środowiskowej u konsumentów z krajów rozwiniętych, zarówno w zakresie braku solidarności z innymi ludźmi, jak i obojętności na degradujący wpływ własnych działań na środowisko naturalne" (Lewicka-Strzałecka 2018, 106).

Skuteczność działań edukacyjnych w zakresie upowszechniania zrównoważonych - odpowiedzialnych społecznie i ekologicznie - wzorców konsumpcji wymaga zintegrowanych i długofalowych działań, a przede wszystkim współpracy pomiędzy podmiotami sektora publicznego - realizującymi politykę gospodarczą, ekologiczną, społeczną i konsumencką państwa - i podmiotami sektora prywatnego (biznesu branż spożywczych) oraz organizacjami sektora pozarządowego (Niedek 2006). Istotne jest budowanie systemu komunikacji edukacyjnej pomiędzy wszystkimi uczestnikami łańcucha dostaw żywności - producentami, przetwórcami, dostawcami, sprzedawcami, restauratorami 
i konsumentami - systemu integrującego działania motywowane etyką biznesu, społeczno-ekologiczną odpowiedzialnością przedsiębiorstw (CSR - corporate social responsibility) i etyką konsumencką (Niedek i Hoffmann-Niedek 2014). Powinny być one ukierunkowane na budowanie aksjologicznych (aretologicznych) i świadomościowych podstaw zrównoważonych decyzji, wyborów i zachowań konsumenckich i pozostałych podmiotów systemu żywnościowego, z naczelną wartością odpowiedzialności ekospołecznej. Jej praktykowanie w odpowiedniej skali i czasie przełoży się na wymierne zmniejszanie poziomu marnotrawstwa żywności, a pośrednio zasobów środowiska i kapitału przyrodniczego (w tym bioróżnorodności), przy jednoczesnym przyczynianiu się - w przypadku odpowiedniej redystrybucji zdatnej do konsumpcji żywności do osób potrzebujących - do zwiększenia kapitału społecznego związanego z praktyką solidarności społecznej.

\section{Podsumowanie}

Marnotrawienie żywności jest złożonym i wielowymiarowym problemem, na który wpływa wiele czynników. Postrzegane jest jako duży problem ekonomiczny, społeczny, ekologiczny, ale również etyczny. Unikanie marnotrawstwa w łańcuchu dostaw żywności od „pola do stołu” wymaga współdziałania między różnymi grupami interesariuszy. Istotne znaczenie dla tych procesów ma normatywna idea i model zrównoważonej konsumpcji żywności. Na podstawie przeglądu literatury przedmiotu i wyników badań prowadzonych w ramach projektu PROM szczególnie ważne będzie zidentyfikowanie czynników socjodemograficznych i psychograficznych o istotnym znaczeniu dla procesu podejmowania decyzji przez konsumentów oraz interdyscyplinarne, holistyczne badanie procesów zrównoważonej konsumpcji w praktyce społecznej, które pozwoli wyodrębnić kluczowe czynniki na etapie zachowań konsumenta i relacji konsument-handel.
Znaczenie konsumentów i gospodarstw domowych w procesach ograniczenia marnotrawienia żywności jest szczególnie istotne w krajach rozwiniętych, gdzie dominuje model niezrównoważonego konsumpcjonizmu. Istnieją przesłanki wskazujące, że problem marnowania żywności w gospodarstwach domowych krajów UE będzie dalej narastać. Wskazuje się, że kompleksowe działania o charakterze edukacyjnym i kształtowania świadomości konsumentów są skuteczne przy odpowiednim poziomie wiedzy i otwartości na nowe modele konsumpcji ze strony szerokiego spektrum interesariuszy sektora prywatnego, publicznego i pozarządowego (Aschemann-Witzel et al. 2015).

Analizy postaw i zachowań konsumentów pokazują, że motywacja do unikania marnowania żywności, umiejętność optymalnego zarządzania zaopatrzeniem w żywność, a także racjonalne gospodarowanie żywnością oraz kompromisy między priorytetami w tym zakresie mają duży wpływ na ograniczanie przyczyn jej marnotrawstwa. Dalsze badania podjętej problematyki powinny koncentrować się na konsumencie żywności i strukturze jego motywacji do przyjęcia modelu zrównoważonej konsumpcji i wdrożenia go do codziennej praktyki konsumenckiej.

\section{Bibliografia}

Aschemann-Witzel, Jessica, Ilona de Hooge, Amani Pegah, Tino Bech-Larsen, and Marija Oostindjer. 2015. “Consumer-Related Food Waste: Causes and Potential for Action." Sustainability 7(6): 6457-6477.

Bilska, Beata, i Danuta Kołożyn-Krajewska. 2016. Model ograniczenia strat i marnowania $\dot{z} y w n o s ́ c i$ z korzyścią dla spoteczeństwa (MOST). Kraków: Wydawnictwo Naukowe PTTŻ.

Bilska, Beata, i Danuta Kołożyn-Krajewska. 2018. "Straty żywności w przetwórstwie żywności." Przemyst Spożywczy 72(1): 23-25.

Bilska, Beata, Małgorzata Wrzosek, Danuta KołożynKrajewska, i Karol Krajewski. 2016. "Risk of food losses and potential of food recovery for social purposes." Waste Management 52: 269-277. 
Bilska, Beata, Małgorzata Wrzosek, Danuta KołożynKrajewska, i Karol Krajewski. 2015. “Food Losses and Food Waste in the Context of Sustainable Development of the Food Sector." Chinese Business Review 14(9): 452-462.

Bilska, Beata, Małgorzata Wrzosek, Karol Krajewski, i Danuta Kołożyn-Krajewska. 2015. "Zrównoważony rozwój sektora żywnościowego a ograniczenie strat i marnotrawstwa żywności." Journal of Agribusiness and Rural Development 2(36): 171-179.

Bilska, Beata, Marzena Tomaszewska, Danuta Kołożyn-Krajewska, and Małgorzata Piecek. 2020. "Segmentation of Polish Households Taking into Account Food Waste." Foods 9(4): 379-398.

Centrum Naukowe UE. 2020. EU burden from non-communicable diseases and key risk factors. Accessed November 03, 2020. https:// ec.europa.eu/jrc/en/health-knowledge-gateway/ societal-impacts/burden.

Decyzja delegowana Komisji 2019 - Decyzja delegowana Komisji (UE) 2019/1597 z dnia 3 maja 2019 r. uzupełniająca dyrektywę Parlamentu Europejskiego i Rady 2008/98/WE w odniesieniu do wspólnej metody i minimalnych wymagań jakościowych dla jednolitego pomiaru poziomów odpadów żywności. Dz.U. L 248, ss. 77-85, z 27.09.2019.

FAO and WHO. 2019. Sustainable healthy diets guiding principles. Rome: Food and Agriculture Organization of the United Nations; World Health Organization.

FUSIONS. 2015. Fusions Food waste data set for EU-28. New Estimates and Environmental Impact. Accessed January 14, 2021. https://ec.europa.eu/ food/sites/food/files/safety/docs/fw_lib_fw_ expo2015_fusions_data-set_151015.pdf.

FUSIONS. 2016. Food waste quantification manual to monitor food waste amounts and progression. Accessed January 14, 2021. https://www.eu-fusions. org/phocadownload/Publications/FUSIONS\%20 Food\%20Waste\%20Quantification\%20Manual.pdf. Ganowicz-Bączyk, Anita. 2015. „Narodziny i rozwój etyki środowiskowej." Studia Ecologiae et Bioethicae 13(4): 39-63.

Gustavsson, Jenny, Christel Cederberg, Ulf Sonesson, Robert van Otterdijk, and Alexandre Meybeck. 2011. Global Food Losses and Food Waste. Extent, Causes and Prevention. Rome: FAO.
Jastrzębska-Smolaga, Halina. 2000. W kierunku trwałej konsumpcji. Dylematy, zagrożenia, szanse. Warszawa: Wydawnictwo Naukowe PWN.

Kiełczewski, Dariusz. 2004. Konsumpcja a perspektywy trwatego $i$ zrównoważonego rozwoju. Białystok: Wydawnictwo Uniwersytetu w Białymstoku.

Kołożyn-Krajewska, Danuta, Karol Krajewski, Beata Bilska, i Małgorzata Wrzosek. 2016. „Przyczyny strat żywności w łańcuchu żywnościowym." W Model ograniczenia strat $i$ marnowania żywności z korzyścia dla spoteczeństwa (MOST), red. Beata Bilska, Danuta Kołożyn-Krajewska, 17-22. Kraków: Wydawnictwo Naukowe PTTŻ.

Komunikat Komisji 2008 - Komunikat Komisji do Parlamentu Europejskiego, Rady, Europejskiego Komitetu Ekonomiczno-Społecznego oraz Komitetu Regionów dotyczacy planu działania na rzecz zrównoważonej konsumpcji i produkcji oraz zrównoważonej polityki przemystowej, $\mathrm{COM}(2008)$ 397, Bruksela, 16.07.2008. Dostęp 14.01.2021. https://eur-lex.europa.eu/legal-content/PL/TXT/ PDF/?uri=CELEX:52008DC0397\&from=PL.

Komunikat Komisji 2018 - Komunikat Komisji do Parlamentu Europejskiego, Rady, Europejskiego Komitetu Ekonomiczno-Spotecznego i Komitetu Regionów w sprawie monitorowania gospodarki o obiegu zamkniętym. COM/2018/029 final, z 16.01. 2018. Dostęp 14.01.2021. https:// eur-lex.europa.eu/legal-content/PL/TXT/ PDF/?uri=CELEX:52018DC0029\&from=PL.

Komunikat Komisji 2020 - Komunikat Komisji do Parlamentu Europejskiego, Rady, Europejskiego Komitetu Ekonomiczno-Społecznego oraz Komitetu Regionów Strategia „od pola do stołu” na rzecz sprawiedliwego, zdrowego i przyjaznego dla środowiska systemu żywnościowego, COM(2020) 381, Bruksela, 20.05.2020. Dostęp 14.01.2021. https:/eur-lex.europa.eu/legal-content/PL/TXT/ PDF/?uri=CELEX:52020DC0381\&from=PL.

Kosseva, Maria R., and Colin Webb. 2013. Food Industry Wastes-Assessment and Recuperation of Commodities. London: Elsevier Science Publishing. Krajewski, Karol, and Milena Lipińska. 2017. "Reduction of losses in the distribution of dairy products as part of product management." Studia Oeconomica Posnaniensia 5(7): 149-161.

Krajewski, Karol, Mikołaj Niedek, Sylwia Łaba, Krystian Szczepański, i Bolesław Borkowski. 
2019. "Methodological Barriers of Monitoring and Research of Food Losses and Waste (FLW)." Quantitative Methods in Economics 20(1): 20-34. Kwasek, Mariola. 2016. Z badań nad rolnictwem społecznie zrównoważonym. 37. Analiza strat i marnotrawstwa żywności na świecie $i$ w Polsce. Warszawa: Instytut Ekonomiki Rolnictwa i Gospodarki Żywnościowej - Państwowy Instytut Badawczy.

Łaba, Sylwia. 2020. Straty i marnotrawstwo żywości $w$ Polsce. Skala i przyczyny problemu. Warszawa: Instytut Ochrony Środowiska - Państwowy Instytut Badawczy.

Lewicka-Strzałecka, Anna. 2003. „Konsumeryzm kontra konsumeryzm." Annales. Etyka w życiu gospodarczym 6: 132-138.

Lewicka-Strzałecka, Anna. 2018. „Etyka konsumenta w perspektywie aretologicznej." Diametros 56: 89109. https://doi.org/10.13153/diam.56.1208.

Monier, Véronique, Shailendra Mudgal, Victoire Escalon, Clementine O'Connor, Thomas Gibon, Gina Anderson, and Hortense Montoux. 2010 Final Report - Preparatory Study on Food Waste Across EU 27. European Commission. BIO Intelligence Service, Brussels. https://doi. org $/ 10.2779 / 85947$.

Niedek, Mikołaj, i Anna Hoffmann-Niedek. 2014. „Produkcja ekologiczna a zrównoważona w świetle odpowiedzialności biznesu." Optimum. Studia Ekonomiczne 4(70): 46-60.

Niedek, Mikołaj, Sylwia Łaba, Anna KamińskaDwórznicka, Karol Krajewski, i Krystian Szczepański. 2019. „Definiowanie strat i marnotrawstwa żywności." Żywność. Nauka. Technologia. Jakość 4(121): 5-16.

Niedek, Mikołaj. 2006. „Rola partnerstwa międzysektorowego w równoważeniu wzorców konsumpcji." W Edukacja konsumencka. Cele, instrumenty, dobre praktyki, red. Anna LewickaStrzałecka, 135-154. Warszawa: WSPiZ.

Niedek, Mikołaj. 2020. „Filozofia trwałości konsumpcji a marnotrawstwo żywności." Referat wygłoszony podczas XXIV Konferencji Naukowej z cyklu „Filozofia zrównoważonego rozwoju” 19-20 listopada 2020. Warszawa: Uniwersytet Kardynała Stefana Wyszyńskiego w Warszawie.
Parfitt, Julian, Mark Barthel, and Sarah Macnaughton. 2010. "Food waste within food supply chains: quantification and potential for change to 2050." Philosophical Transactions of the Royal Society Biological Sciences 365(1554): 3065-3081.

Quested, Tom, Robert Ingle, and Andrew Parry. 2012. Household Food and Drink Waste in the United Kingdom. 2012, Final Report. Accessed January 14, 2021. http://www.wrap.org.uk/sites/files/wrap/ hhfdw-2012-main.pdf.pdf.

Rezolucja Parlamentu Europejskiego 2012 - Rezolucja Parlamentu Europejskiego z dnia 19 stycznia 2012 r. Jak uniknać marnotrawienia żywności: strategie na rzecz poprawy wydajności tańcucha żywnościowego w UE (2011/2175(INI)) (Dz.U. UE z 6.08.2013 r., C 227 E/25). Dostęp 14.01.2021. https://eur-lex.europa.eu/legal-content/PL/TXT/ PDF/?uri=CELEX:52012IP0014\&from=PL.

Śmiechowska, Marta. 2015. „Zrównoważona konsumpcja a marnotrawstwo żywności." Annales Academiae Medicae Gedanensis 45(1): 79-87.

Stępień, Sebastian, i Dawid Dobrowolski. 2017. „Straty i marnotrawstwo w łańcuchu dostaw żywności - propedeutyka problemu." Progress in Economic Science 4: 305-316.

Stuart, Tristram. 2009. Waste: Uncovering the Global Waste Scandal. London: Penguin.

Tyburski, Włodzimierz 1999. „Główne kierunki i zasady etyki środowiskowej." W Wprowadzenie do filozoficznych problemów ekologii, red. Andrzej Papuziński, 97-132. Bydgoszcz: Wydawnictwo WSP w Bydgoszczy.

Ustawa z dnia 19 lipca 2019 r. o przeciwdziałaniu marnowaniu żywności (Dz.U. 2019, poz. 1680).

Willett, Walter, Johan Rockström, Brent Loken, Marco Springmann, et al. 2019. "Food in the Anthropocene: the EAT-Lancet Commission on healthy diets from sustainable food systems." The Lancet 393(10170): 447-492.

Wrzosek, Małgorzata, Beata Bilska, Danuta KołożynKrajewska, i Karol Krajewski. 2017. „Zastosowanie analizy ryzyka do opracowania innowacyjnego systemu ograniczania strat i marnowania żywności w handlu detalicznym (system MOST)." Żywność. Nauka. Technologia. Jakość 24(2): 140-155. 